\title{
Densitometric analysis of the autogenous demineralized dentin matrix on the dental socket wound healing process in humans
}

\section{Análise densitométrica da matriz dentinária desmineralizada autógena na reparação alveolar de humanos}

\author{
Mônica Fernandes Gomes* \\ Paula Pinheiro de Abreu** \\ Aline Rose Cantarelli Morosolli*** \\ Marcelo Marotta Araújo**** \\ Maria das Graças Vilela Goulart*****
}

\begin{abstract}
The aim of this study was to evaluate the effects of the autogenous demineralized dentin matrix $(\mathrm{ADDM})$ on the third molar socket wound healing process in humans, using the guided bone regeneration technique and a polytetrafluoroethylene barrier (PTFE). Twenty-seven dental sockets were divided into three groups: dental socket (Control), dental socket with PTFE barrier (PTFE), and dental socket with ADDM slices associated to PTFE barrier (ADDM + PTFE). The dental sockets were submitted to radiographic bone densitometry analysis and statistical analysis on the $15^{\text {th }}, 30^{\text {th }}, 60^{\text {th }}$ and $90^{\text {th }}$ days using analysis of variance (ANOVA) and Tukey's test $(p \leq 0.05)$. The radiographic analysis of the ADDM + PTFE group showed greater homogeneity of bone radiopacity than the Control group and the PTFE group, during all the observation times. The dentin matrix gradually disappeared from the dental socket during the course of the repair process, suggesting its resorption during the bone remodeling process. It was concluded that the radiographic bone density of the dental sockets treated with ADDM was similar to that of the surrounding normal bone on the $90^{\text {th }}$ day. The ADDM was biocompatible with the bone tissue of the surgical wounds of human dental sockets. The radiographic analysis revealed that the repair process was discreetly faster in the ADDM + PTFE group than in the Control and PTFE groups, although the difference was not statistically significant. In addition, the radiographic image of the ADDM + PTFE group suggested that its bone architecture was better than that of the Control and PFTE groups.
\end{abstract}

DESCRIPTORS: Bone regeneration; Dentin; Tissue engineering.

\begin{abstract}
RESUMO: O objetivo desta pesquisa foi avaliar a reparação óssea em alvéolos dentários após exodontia dos terceiros molares inferiores em humanos, com implantação de matriz dentinária desmineralizada autógena (MDDA) na cavidade e cobertura desta com barreira de politetrafluoretileno (PTFE). Foram selecionados 27 dentes, os quais foram divididos em três grupos: alvéolo dentário (Controle), alvéolo dentário com barreira de PTFE (PTFE) e alvéolo dentário com fatias de MDDA associada à barreira de PTFE (MDDA + PTFE). O alvéolo dentário foi submetido à análise de densitometria radiográfica e à análise estatística no $15^{\circ}, 30^{\circ}, 60^{\circ}$ e $90^{\circ}$ dias, utilizando-se a análise de variância (ANOVA) e teste de Tukey $(\mathrm{p} \leq 0,05)$. A análise radiográfica do grupo MDDA + PTFE mostrou maior homogeneidade na radiopacidade do trabeculado ósseo do que no grupo controle e grupo PTFE, durante todos os períodos de observação. A matriz dentinária foi desaparecendo do alvéolo dentário durante a evolução do processo de reparo, sugerindo sua reabsorção durante o processo de remodelação óssea. Concluiu-se que a densidade óssea radiográfica do alvéolo dentário tratado com MDDA foi similar à do osso normal circunjacente no $90^{\circ}$ dia. A MDDA foi biocompativel com o tecido ósseo, quando implantada nos alvéolos dentários cruentos de humanos. Na análise radiográfica, pode-se verificar que o processo de reparo foi discretamente mais rápido no grupo MDDA + PTFE do que no grupo Controle e no grupo PTFE, porém não houve diferença estatística significante. Além disso, a imagem radiográfica sugeriu que a arquitetura óssea do grupo MDDA + PTFE foi melhor do que a arquitetura óssea do grupo controle e grupo PTFE.
\end{abstract}

DESCRITORES: Regeneração óssea; Dentina; Engenharia tissular.

\footnotetext{
* PhD, Chairman of the Special Health Care Needs Association (ASPE).

** Resident, Bioscience Center for Special Health Care Needs (CEBAPE); ***Postdoctoral Research Fellow, Academic Group of Studies and Research with Laser in Dentistry; ${ }^{* * * *} \mathrm{PhD}$, Professor, Department of Surgery, Periodontology and Radiology; $* * * * * \mathrm{MS}$, Postdoctoral Research Fellow, Bioscience Center for Special Health Care Needs (CEBAPE) - School of Dentistry of São José dos Campos, São Paulo State University.
} 
Gomes MF, Abreu PP, Morosolli ARC, Araújo MM, Goulart MGV. Densitometric analysis of the autogenous demineralized dentin matrix on the dental socket wound healing process in humans. Braz Oral Res 2006;20(4):324-30.

\section{INTRODUCTION}

The repair of bone defects resulting from trauma, infections, neoplasias or developmental abnormalities represents a challenge for maxillomandibular complex surgeries. ${ }^{4}$ Several researches have presented some materials that have osteopromotive potential for osteogenesis. The dentin matrix used as implant biomaterial has osteogenic and chemotactic potential. Some authors have reported that autogenous demineralized dentin matrix slices (ADDM) stimulated bone neoformation. ${ }^{1,10}$

Osteopromotion is a concept that has been incorporated into the bone repair process and it can be defined as the ability to induce bone formation using bone regeneration techniques. Its objective is to guide sufficient bone neoformation in order to close any bone defect in maxillomandibular processes. This phenomenon is probably controlled by complex molecular interactions, cellular messages of short or long extension, affecting the speed and duration of the osteoblastic and osteoclastic activity, as well as proliferation, differentiation, and chemotaxis of special cells..$^{3,7,9,13}$ Some authors have stated that cellular proliferation begins with local stimulating factors, that are bone morphogenetic proteins (BMP). ${ }^{1,3,9}$ In addition to BMP, ADDM slices are also rich in other growth factors such as transforming growth factor-beta (TGF-beta), fibroblast growth factor (FGF), platelet-derived growth factor (PDGF) and epidermal growth factor (EGF). ${ }^{2,6,8}$

The present study evaluated radiographic bone density and the effects of ADDM on the third molar socket wound healing process in humans, using the guided bone regeneration technique with PTFE barrier.

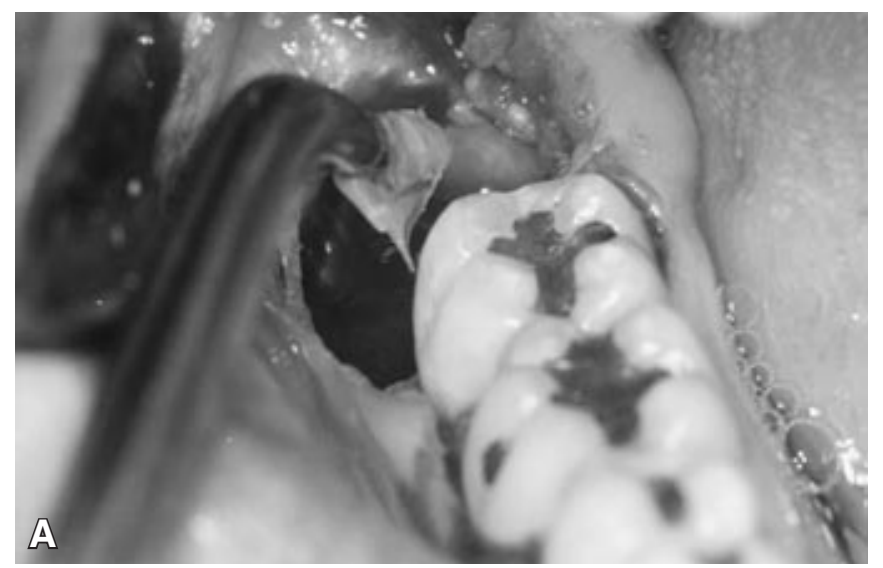

\section{MATERIAL AND METHODS}

The present study was performed at the Special Health Care Needs Association (ASPE, Brazil) and Bioscience Center for Special Health Care Needs (CEBAPE/UNESP, Brazil), with fourteen patients (11 female and three male, aged $15-40$ years). The 27 dental sockets of lower third molars were divided into three groups: Control group (dental socket with no treatment), PTFE group (dental socket covered by PTFE barrier), and ADDM + PTFE (dental socket with ADDM and regeneration guided bone technique using PTFE barrier). The ADDM was obtained by extraction and slicing of a lower third molar of the PTFE group, according to Gomes et al. ${ }^{7}$ (2001). The ADDM slices with approximately $8 \mu \mathrm{m}$ in thickness were immersed in a sterile glass container filled with a $0.2 \mathrm{ml}$ gentamicin solution of $70 \%$ ethyl alcohol (q.s. $5 \mathrm{ml}$ ) and stored at $2^{\circ} \mathrm{C}$ until the time of implantation (Figures 1a and 1b). The tooth extractions were performed after local anesthesia with Biopres$\sin (2 \%$ lidocaine) and a Felipressin solution $(0.02$ $\mathrm{IU})$, and all patients were treated with an antibiotic (Amoxicillin, $500 \mathrm{mg}$ ) and an antiinflammatory (potassium diclophenac, $100 \mathrm{mg}$ ) three times a day for 5 days, by oral administration; an analgesic (Paracetamol $750 \mathrm{mg}$ ) was administered in case of pain. These patients were also instructed to rinse the surgery area with a $0.12 \%$ chlorhexidine solution for five to seven weeks post-surgically. Four weeks after temporary implantation, the PTFE barriers were removed in a second surgical procedure. The dental sockets were clinically examined on the $15^{\text {th }}, 30^{\text {th }}$, $60^{\text {th }}$, and $90^{\text {th }}$ day after surgery. Nine dental sockets of each group were submitted to radiographic examination by periapical radiographs utilizing the

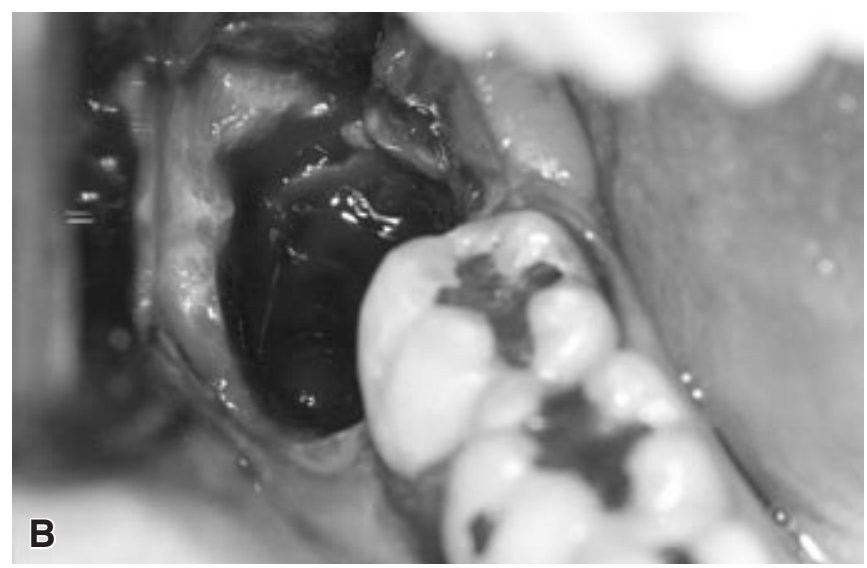

FIGURE 1 - Implantation of ADDM slices in the dental socket $(\mathbf{A})$ and dental socket with ADDM slices covering its surface (B). 
Gomes MF, Abreu PP, Morosolli ARC, Araújo MM, Goulart MGV. Densitometric analysis of the autogenous demineralized dentin matrix on the dental socket wound healing process in humans. Braz Oral Res 2006;20(4):324-30.

paralleling technique, and radiographic bone density analysis was carried out. Statistical analysis of the radiographic bone density data included analysis of variance (ANOVA) and Tukey's test ( $p \leq 0.05)$ (GraphPad Prisma version 2.00 for WindowsXP, GraphPad Software, San Diego, California, USA).

\section{Radiographic bone density analysis}

The conventional periapical radiographs were taken using AGFA periapical films $(3.5 \times 4.5 \mathrm{~cm}$, Agfa Gevaert Dentus M2 Comfort, Gevaert-Agfa N. V., Amberes, Belgium), exposed at $65 \mathrm{kVp}$ and $10 \mathrm{~mA}$ for 0.80 seconds with a Dabi-Atlante SPECTRO 70X dental X-ray (Dabi Atlante S/A Ribeirão Preto, São Paulo, Brazil) and a target-film distance of $40 \mathrm{~cm}$. Automatic processing was done at $27^{\circ} \mathrm{C}$, in a Gendex GXP automatic processor (Gendex Corporation, Des Plaines, Illinois, USA) with a 6 minute cycle. Freshly mixed developer and fixer solutions were used to ensure proper processing. Each radiograph was measured individually with the aid of a positioner, with a fixed reference point to enable precise reproducibility ${ }^{5}$. An aluminum step-wedge was placed in the edges of all radiographic films to better evaluate and compare the radiographic bone density of the periapical radiographs..$^{11,12}$ Three experienced professionals were selected for radiographic interpretation. They compared the radiographic bone density of each part of the socket (apical, medium and cervical areas) and then compared it to the density of each thickness of the step-wedge, which is expressed in millimeters of aluminum equivalent. Ten measurements were performed for each radiograph (five immediately after developing the periapical radiographs and five after two weeks). An average was then obtained ${ }^{11}(\mathrm{mmAl})$ and the values were submitted to statistical analysis.

\section{RESULTS \\ Radiographic analysis \\ Control group}

On the $15^{\text {th }}$ day (Figure $2 \mathrm{a}$ ), thin radiopaque lines were observed representing trabecular bone with a disorganized pattern, extending from the cortical bone walls to the central portion of the socket, which indicated a centripetal growth. The alveolar cortical, represented by a radiographic line, was evident. The mesial portion of the socket showed a higher degree of radiographic bone density than the distal third. The cervical area was more radiolucent than the other areas. On the $30^{\text {th }}$ day, the alveolar cortical was more radiolucent in the apical area, and an increase in radiopacity in the medium third area of the dental socket occurred, showing a more homogeneous aspect when compared with that of the previous period. On the $60^{\text {th }}$ day, the alveolar cortical was irregular and the limits were no longer evident. An increase in density of the dental socket bone was also observed when compared with that of the previous periods, which suggested bone neoformation. The bone aspect was homogeneous at the cervical, medium and apical areas of the dental socket. On the $90^{\text {th }}$ day (Figure $2 \mathrm{~b}$ ), there was a discrete image of an alveolar cortical in the medium third of the dental sockets, with interlinked and radiopaque lines, when the bone repair was almost complete. These lines probably indicated the arrangement of the bone trabeculae after wound healing. During all the evaluation, it was noticed that the radiographic bone density increased in the dental socket extending from the alveolar cortical to the central portion of the dental socket and from the apical area to the cervical area.
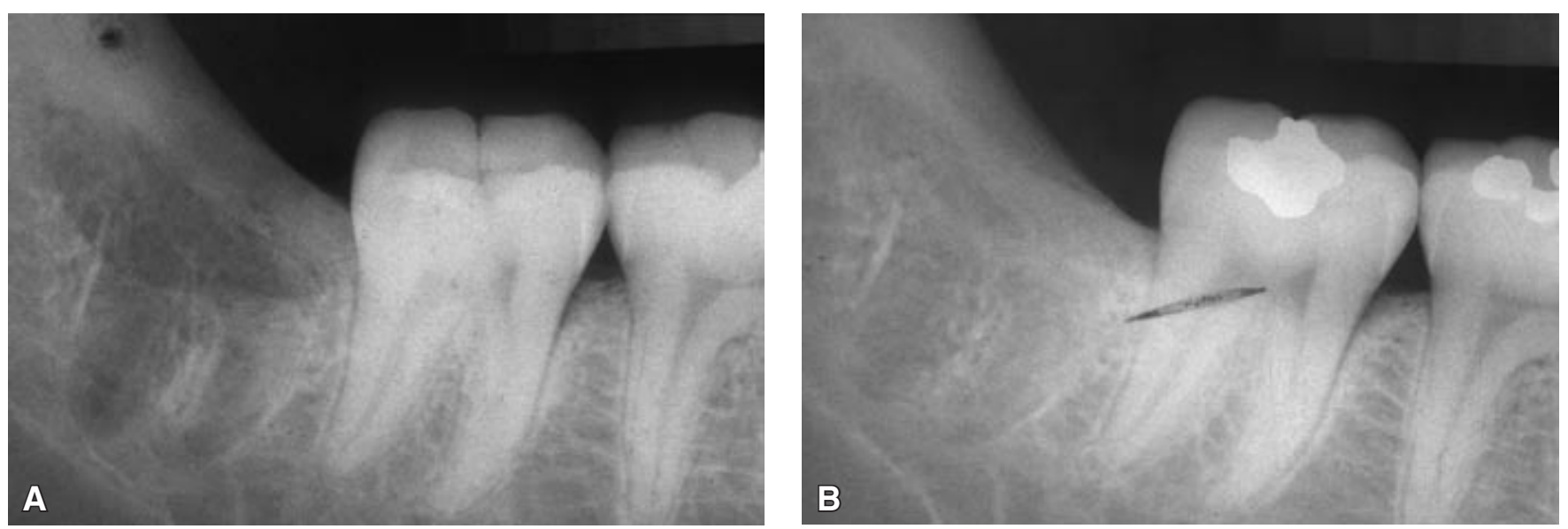

FIGURE 2 - Periapical radiographs after 15 days (A), and 90 days (B) post-surgery - control group. 
Gomes MF, Abreu PP, Morosolli ARC, Araújo MM, Goulart MGV. Densitometric analysis of the autogenous demineralized dentin matrix on the dental socket wound healing process in humans. Braz Oral Res 2006;20(4):324-30.
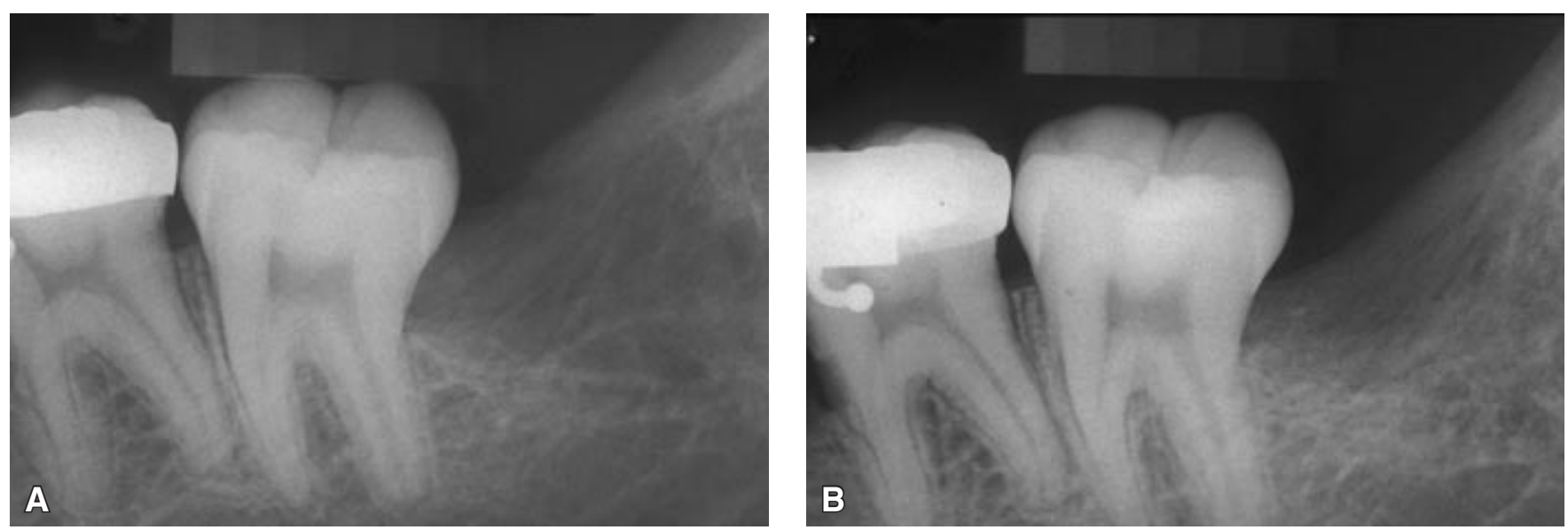

FIGURE 3 - Periapical radiographs after 15 days (A), and 90 days (B) post-surgery - PTFE group.

\section{PTFE Group}

On the $15^{\text {th }}$ day (Figure $3 \mathrm{a}$ ), the alveolar cortical feature was represented by a radiopaque image, and the radiographic bone density in the apical area was more evident and homogeneous. On the $30^{\text {th }}$ day the alveolar cortical was losing delimitation and was irregular in its entire contour. There was higher radiopacity in the apical area than in the medium and cervical areas, indicating new bone formation in an apical to cervical direction. On the $60^{\text {th }}$ day, a diffuse aspect of the alveolar cortical and an increase in the radiopacity of the medium and cervical areas were observed. The apical area was homogeneous and had a radiographic image similar to that of normal bone. On the $90^{\text {th }}$ day (Figure $3 \mathrm{~b}$ ), the dental socket presented an increase in radiographic bone density, mostly in the medium area, with a disorganized pattern. During all the evaluation periods, a progressive and gradual increase in radiographic bone density was observed, extending from the limits to the central portion of the dental socket, and from the apical to the cervical portion of it.

\section{ADDM + PTFE Group}

On the $15^{\text {th }}$ day (Figure 4 a), a radiopaque image was clearly observed inside the alveolar socket, suggesting remaining ADDM slices (arrow) implanted post-extraction, located between the medium and cervical thirds. It was observed that the presence of ADDM slices did not interfere with the regular repair process. An alveolar cortical image was not seen clearly. On the $30^{\text {th }}$ day, a radiopaque image suggesting remaining ADDM slices presented a small shape when compared with that seen on the $15^{\text {th }}$ day, suggesting resorption of the ADDM slices during the bone remodeling process. On the $60^{\text {th }}$ day, the radiopaque images suggestive of bone trabeculae showed a more organized pattern when compared with that of the previous periods. On the $90^{\text {th }}$ day (Figure $4 \mathrm{~b}$ ), the region of the dental socket had been completely replaced by new bone tissue with density similar to that of the normal bone previously surrounding the dental socket. The region of the dental socket showed an organized pattern of radiopacity, compatible with that of normal bone healing density. It was also seen that the radiographic quality of the bone architecture of the ADDM + PTFE group was better than that observed in the Control group and PTFE group.

\section{Radiographic bone density and statistical analysis}

The purpose of the densitometric analysis was to measure the radiographic bone density of the newly formed bone in the dental sockets of the experimental groups, providing the necessary data for statistical analysis. The values related to radiographic bone density within the same experimental group showed a balanced bone neoformation process in all the studied groups. After the analysis of variance was performed, the mean and standard deviations of the newly formed bone radiographic densities were obtained and calculated for each experimental group. Tukey's test was applied at a 5\% significance level. It was observed that the repair process was discreetly faster in the ADDM + PTFE group than in the Control group and PTFE group, although these differences were not statistically significant. However, we observed that there was a 
Gomes MF, Abreu PP, Morosolli ARC, Araújo MM, Goulart MGV. Densitometric analysis of the autogenous demineralized dentin matrix on the dental socket wound healing process in humans. Braz Oral Res 2006;20(4):324-30.
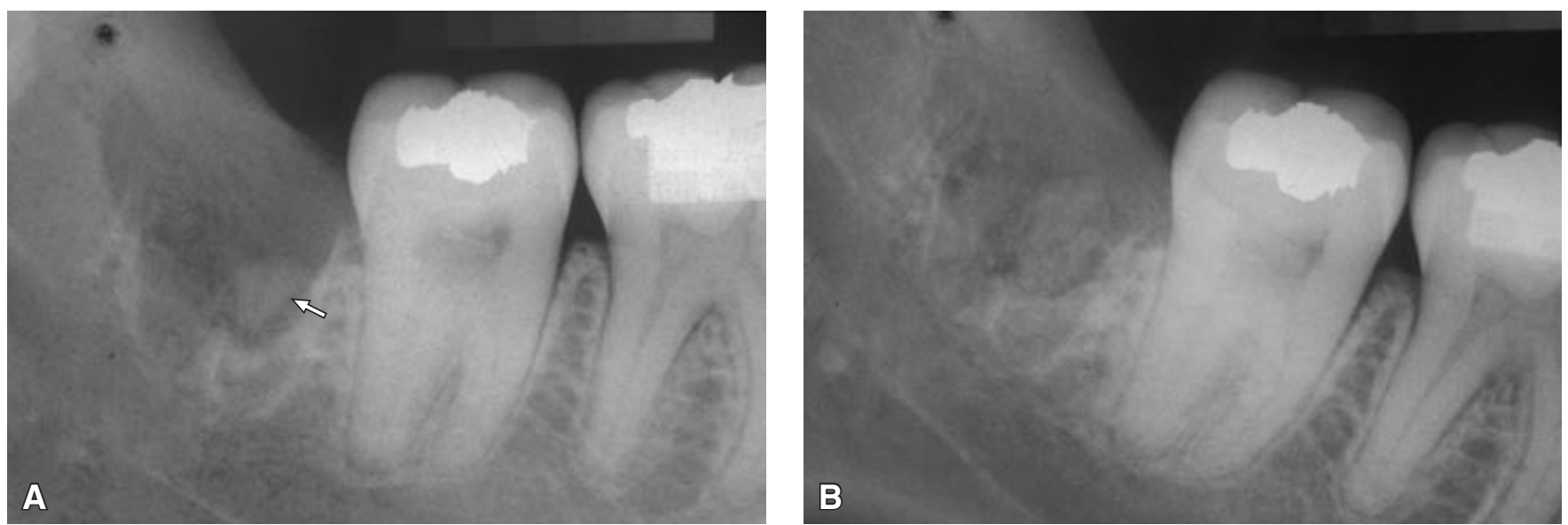

FIGURE 4 - Periapical radiographs after 15 days (A), and 90 days (B) post-surgery - ADDM + PTFE group. Arrow: radiopaque image suggestive of remaining ADDM slices.

TABLE 1 - Radiographic density (mmAl) of the newly formed bone in the studied groups after the observation periods (Mean $\pm \mathrm{SD}, \mathrm{n}=9$ ).

\begin{tabular}{l|c|c|c}
\hline \hline Periods & Control & PTFE & ADDM \pm PTFE \\
\hline 15 days & $1.02 \pm 0.11$ & $0.90 \pm 0.14$ & $1.06 \pm 0.25$ \\
\hline 30 days & $1.20 \pm 0.10$ & $1.04 \pm 0.13$ & $1.24 \pm 0.23$ \\
\hline 60 days & $1.49 \pm 0.07$ & $1.37 \pm 0.11$ & $1.42 \pm 0.17$ \\
\hline 90 days & $1.58 \pm 0.06$ & $1.52 \pm 0.09$ & $1.60 \pm 0.08$ \\
\hline \hline
\end{tabular}

progressive increase in the statistical significance of the differences between the evaluation times in each studied group (Table 1). The means and SD of the radiographic bone densities ( $\mathrm{mmAl}$ ) during the bone repair process in the control, PTFE and ADDM + PTFE groups during the evaluated times are observed in Graph 1.

\section{DISCUSSION}

In the last years, researchers have associated growth factors such as insulin growth factor, platelet-derived growth factor and bone morphogenetic proteins ${ }^{3,6}$ to occlusive membranes in order to accelerate bone repair process. The presence of these growth factors in bone matrix and dentin matrix was reported by Bessho et al. ${ }^{1}$ (1990), Carvalho et al. ${ }^{2}$ (2004), Catanzaro-Guimarães et al. ${ }^{4}$ (1986), and Catanzaro-Guimarães ${ }^{3}$ (1993), who also explained their osteoinductive activity.

In every period studied and in all experimental groups in which a PTFE barrier was used in the present study, the maintenance and integrity of this barrier was observed in its whole extension.

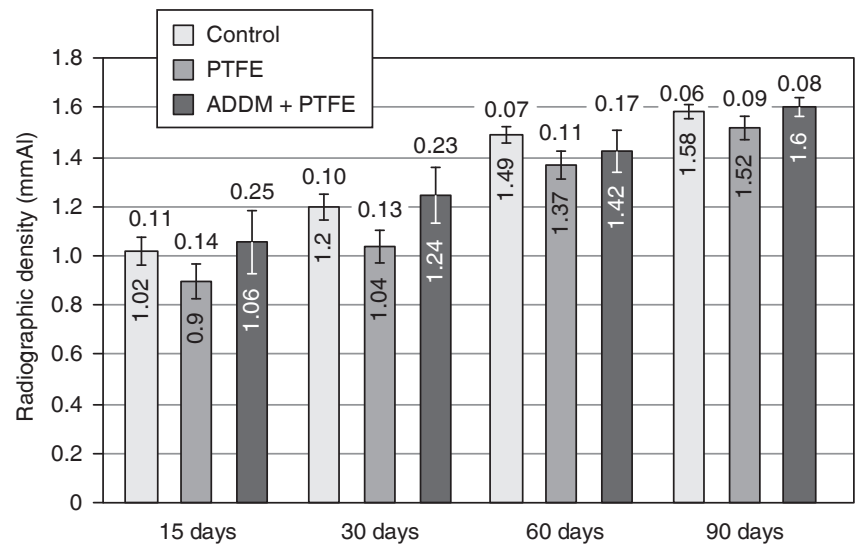

GRAPH 1 - Schematic representation of the means and standard deviations of the radiographic bone densities (mmAl) during the bone repair process in the studied groups.

The methodology used in the present study was not ideal to prove the ADDM osteopromotive activity as declared by Carvalho et al. ${ }^{2}$ (2004), CatanzaroGuimarães $^{3}$ (1993), Gomes et al. ${ }^{6,7}$ (2001, 2002). However, it could be observed that the dentin matrix promoted the formation of a more homogenous and uniform trabecular bone in the three thirds of the dental socket during the 15-day and 30-day periods of healing, characterizing its osteoconductive property in dental socket repair. According to Carvalho et al. ${ }^{2}$ (2004) and Gomes et al. ${ }^{7}$ (2001), the protein substrate of the ADDM was free of degradation, which could have aided the dental socket repair. Gomes et al. ${ }^{6}$ (2002) observed an increase in the osteogenic cell population after implantation of ADDM in wounds. These facts could explain the radiographic aspects observed in the ADDM + PTFE group on the $15^{\text {th }}$ day and $30^{\text {th }}$ day after surgery. 
Gomes MF, Abreu PP, Morosolli ARC, Araújo MM, Goulart MGV. Densitometric analysis of the autogenous demineralized dentin matrix on the dental socket wound healing process in humans. Braz Oral Res 2006;20(4):324-30.

In that group, the radiopaque images, suggestive of trabecular bone, were more homogeneous and uniform in the three thirds of the dental socket when compared to those of the Control and PTFE groups. Moreover, the pattern of these images was more organized and well distributed in all thirds when compared to that of the Control and PTFE groups. It is believed that the disorganized pattern of the radiopaque images on the $90^{\text {th }}$ day of the ADDM + PTFE group was probably already due to resorption of the ADDM slices. This may be confirmed by the fact that ADDM resorption during the bone remodeling process on the $30^{\text {th }}$ day and on the $60^{\text {th }}$ day has also been observed by Gonçalves, Catanzaro-Guimarães ${ }^{9}$ (1998), Gomes et al. ${ }^{6,7}(2001,2002)$ and Carvalho et al. ${ }^{2}$ (2004). In the present research, on the $60^{\text {th }}$ day and on the $90^{\text {th }}$ day, bone remodeling showed little influence of ADDM, which could justify the disorganized pattern of the radiopaque lines of the trabecular bone on the $90^{\text {th }}$ day of observation.

Statistical analysis of the radiographic bone density showed no significance at the $5 \%$ level for the groups studied within each observation period. There was significant differences in relation to the quantity of bone neoformation in each evaluation period. Therefore, the course of the bone repair process was coherent in all the studied groups during all the periods of observation.

Based on the radiographic analysis, we could also observe that the repair process was discreetly faster in the ADDM + PTFE group than in the Control group and PTFE group, however there was no statistical difference. The images revealed an increase in radiographic bone density oriented from the apical to the cervical third of the dental socket and from the alveolar cortical to the central area

\section{REFERENCES}

1. Bessho K, Tagawa T, Murata M. Purification of rabbit bone morphogenetic protein derived from bone, dentin, and wound tissue after tooth extraction. J Oral Maxillofac Surg. 1990;48(2):162-9.

2. Carvalho VA, Tosello Dde O, Salgado MA, Gomes MF. Histomorphometric analysis of homogenous demineralized dentin matrix as osteopromotive material in rabbit mandibles. Int J Oral Maxillofac Implants. 2004;19(5):679-86.

3. Catanzaro-Guimarães SA. Possibility to reinforce bone repair with decalcified dentin matrix. In: Gesellschaft für orale Implantologie, editor. Jahrbuch für orale Implantologie. Berlin: Quintessenz; 1993. p. 33-4.

4. Catanzaro-Guimarães SA, Catanzaro-Guimarães B, Garcia $\mathrm{RB}$, Alle N. Osteogenic potential of autogenic demineralized of the dental socket, characterizing a centripetal and inferior-superior growth direction. A centripetal growth was also noticed by Carvalho et al. ${ }^{2}$ (2004), Gomes et al. ${ }^{6,7}(2001,2002)$ and Gonçalves, Catanzaro-Guimarães ${ }^{9}$ (1998). The ADDM properties observed in this study were osteoconduction and biocompatibility since patient tolerance was excellent in the group treated with it. After so many research tests, ADDM could be recommended for the practice of clinical dentistry.

\section{CONCLUSIONS}

The radiographic bone density of the dental sockets treated with ADDM was similar to that of the surrounding normal bone on the $90^{\text {th }}$ day. The ADDM was biocompatible with surgical human dental sockets. Based on the radiographic analysis, we could observe that the repair process was discreetly faster in the ADDM + PTFE group than in the Control and PTFE groups, although there were no statistical differences. However, the radiographic image of the ADDM + PTFE group suggested that its bone architecture was better than that of the Control group and PTFE group.

\section{ACKNOWLEDGEMENTS}

This research was supported by a grant from the State of São Paulo Research Foundation (FAPESP, process n. 2002/03952-8) and a grant from the Foundation for the Development of the São Paulo State University (FUNDUNESP, process n. 00305-02 DFP). The authors are grateful to the Quaglia Laboratory, São José dos Campos, São Paulo, Brazil. dentin implanted in bony defects in dog. Int J Oral Maxillofac Surg. 1986;15(2):160-9.

5. Duinkerke AS, Van De Poel AC, Doesburg WH, Lemmens WA. Densitometric analysis of experimentally produced periapical radiolucencies. Oral Surg Oral Med Oral Pathol. 1977;43(5):782-97.

6. Gomes MF, dos Anjos MJS, Nogueira Tde O, CatanzaroGuimarães SA. Autogenous demineralized dentin matrix for tissue engineering applications: radiographic and histomorphometric studies. Int $\mathrm{J}$ Oral Maxilofac Implants. 2002;17(4):488-97.

7. Gomes MF, dos Anjos MJ, Nogueira TO, Guimarães SA. Histologic evaluation of the osteoinductive property of autogenous demineralized dentin matrix on surgical bone de- 
Gomes MF, Abreu PP, Morosolli ARC, Araújo MM, Goulart MGV. Densitometric analysis of the autogenous demineralized dentin matrix on the dental socket wound healing process in humans. Braz Oral Res 2006;20(4):324-30.

fects in rabbit skulls using human amniotic membrane for guided bone regeneration. Int $\mathrm{J}$ Oral Maxillofac Implants. 2001;16(4):563-71.

8. Gonçalves EAL, Pavan AJ, Tavano O, Catanzaro-Guimarães SA. Atividade morfogenética da matriz dentinária desmineralizada: estudo em cães. Rev Fac Odontol Bauru. 2002;10(1):51-6.

9. Gonçalves EL, Catanzaro-Guimarães SA. Proteínas morfogenéticas ósseas: terapêutica molecular no processo de reparo ósseo. Rev Odontol Univ São Paulo. 1998;12(3):299304.

10. Kawai T, Urist MR. Bovine tooth-derived bone morphogenetic protein. J Dent Res. 1989;68(6):1069-74.
11. Kolbeck S, Bail H, Weiler A, Windhagen H, Haas N, Raschke M. Digital radiography. A predictor of regenerate bone stiffness in distraction osteogenesis. Clin Orthop Relat Res. 1999;(366):221-8.

12. Puppin AAC, Costa NP, Garcia RS. Análise da densidade óptica pela leitura óptica de terceiros molares inferiores em mandíbulas secas. Rev Odonto Ciência. 1998;13(1):15165.

13. Tziafas D, Alvanou A, Panagiotakopoulos N, Smith AJ, Lesot H, Komnenou A et al. Induction of odontoblastlike cell differentiation in dog dental pulps after in vivo implantation of dentine matrix components. Arch Oral Biol. 1995;40(10):883-93.

Received for publication on Feb 15, 2006

Sent for alterations on May 31, 2006

Accepted for publication on Jul 20, 2006 